AperTO - Archivio Istituzionale Open Access dell'Università di Torino

\title{
Aminopropylindenes derived from Grundmann's ketone as a novel chemotype of oxidosqualene cyclase inhibitors.
}

\section{This is the author's manuscript}

Original Citation:

Availability:

This version is available http://hdl.handle.net/2318/132660

since 2016-10-05T16:54:12Z

Terms of use:

Open Access

Anyone can freely access the full text of works made available as "Open Access". Works made available under a Creative Commons license can be used according to the terms and conditions of said license. Use of all other works requires consent of the right holder (author or publisher) if not exempted from copyright protection by the applicable law. 


\section{웅 \\ UNIVERSITÀ DEGLI STUDI DI TORINO}

This Accepted Author Manuscript (AAM) is copyrighted and published by Elsevier. It is posted here by agreement between Elsevier and the University of Turin. Changes resulting from the publishing process - such as editing, corrections, structural formatting, and other quality control mechanisms - may not be reflected in this version of the text. The definitive version of the text was subsequently published in [Stefanie Lange, Marco Keller, Christoph Müller, Simonetta Oliaro-Bosso, Gianni Balliano, Franz Bracher. Aminopropylindenes derived from Grundmann's ketone as a novel chemotype of oxidosqualene cyclase inhibitors European Journal of Medicinal Chemistry 63 (2013) 758-764 DOI: 10.1016/j.ejmech.2013.03.002].

You may download, copy and otherwise use the AAM for non-commercial purposes provided that your license is limited by the following restrictions:

(1) You may use this AAM for non-commercial purposes only under the terms of the CC-BY-NCND license.

(2) The integrity of the work and identification of the author, copyright owner, and publisher must be preserved in any copy.

(3) You must attribute this AAM in the following format: Creative Commons BY-NC-ND license (http://creativecommons.org/licenses/by-nc-nd/4.0/deed.en), [+ Digital Object Identifier link to the published journal article on Elsevier's ScienceDirect ${ }^{\circledR}$ platform $]$ 


\title{
Aminopropylindenes derived from Grundmann's ketone as a novel chemotype of oxidosqualene cyclase inhibitors
}

\author{
Stefanie Lange ${ }^{\mathrm{a}}$, Marco Keller ${ }^{\mathrm{a}}$, Christoph Müller ${ }^{\mathrm{a}}$ Simonetta Oliaro-Bosso ${ }^{\mathrm{b}}$, \\ Gianni Balliano ${ }^{\mathrm{b}}$, Franz Bracher ${ }^{\mathrm{a}, *}$
}

${ }^{a}$ Department für Pharmazie - Zentrum für Pharmaforschung, Ludwig-Maximilians-Universität München, Butenandtstr. 5-13, D-81377 Munich, Germany

${ }^{b}$ Dipartimentodi Scienza e Tecnologia del Farmaco, Università di Torino, Via Pietro Giuria, 9, 10125 Torino, Italy

*Corresponding author. Email: Franz.Bracher@cup.uni-muenchen.de, Phone: +49-89-218077301, Fax: +49-89-2180-77802

\begin{abstract}
A series of aminopropylindenes, designed as mimics of a cationic high energy intermediate in the oxidosqualene cyclase ${ }^{1}$ (OSC)-mediated cyclization of to lanosterol were prepared from Grundmann's ketone. Screening on OSCs from five different organisms revealed interesting activities and selectivities of some of the compounds. A $N, N$-dimethylaminopropyl derivative showed promising inhibition of T. cruzi OSC in combination with low cytotoxicity, and showed significant reduction of cholesterol biosynthesis in a human cell line.
\end{abstract}

Keywords: Oxidosqualene cyclase, enzyme inhibitor, high energy intermediate, secosteroid, species selectivity

\section{Introduction}

Sterol biosynthesis is a complex metabolic pathway in which two sharply different sections are well recognizable: an "assembly section" which is devoted to build the open triterpene 2,3-oxidosqualene starting from the common lipid precursor acetyl-CoA, and a "tailoring section" which remodels the sterol intermediates to generate the end-product (cholesterol,

\footnotetext{
${ }^{1} \mathrm{OSC}=$ oxidosqualene cyclase
} 
ergosterol or phytosterols, in animal, fungal or plant cells, respectively). The two sections are connected by the cyclization of 2,3-oxidosqualene, one of the most outstanding monoenzymatic reactions (if not the most one), that confers the steroid shape to the open triterpene oxidosqualene. This reaction is catalyzed by enzymes belonging to the family of oxidosqualene cyclases (OSC), which form lanosterol in non-photosynthetic organisms and, mostly, cycloartenol in photosynthetic organisms $[1,2]$.

Cyclization of 2,3-oxidosqualene is triggered by the stereospecific protonation of the epoxide ring of the substrate and proceeds through the generation of several carbocationic high energy intermediates (HEIs) both during the formation of the new carbon-carbon bonds for the closure of the four rings-steroid scaffold (in the sequence pro-C4, C10, C8, C13 and C20) and during the rearrangement of the protosteryl carbocation pro- $\mathrm{C} 20$ (in the sequence pro$\mathrm{C} 17, \mathrm{C} 13, \mathrm{C} 14$, and $\mathrm{C} 8$ or $\mathrm{C} 9$ depending on the product) till the removal of a proton and formation of lanosterol or cycloartenol. Studies for unravelling the above complex cyclization reaction had involved a number of laboratories for over fifty years, covering a complete list of expertises and methodologies, from chemical mimicking to protein purification, from inhibitory assays to site-directed mutagenesis [3], till the crystallization of squalene and oxidosqualene cyclizing enzymes [4,5,6].

Oxidosqualene cyclases have been considered attractive targets for designing cholesterol lowering [7], antifungal [8,9], and antiparasitic agents [10,11,12]. Recently, inhibitors of oxidosqualene cyclase proved to be effective as anticancer agents against human cancer cells from various tissue origins [13].

A common concept in the development of inhibitors of sterol (and other) biosynthesis is mimicking of the extremely short-lived carbocationic HEIs, most commonly accomplished by compounds having (a) a protonable aliphatic amino group, or (b) an aliphatic amine-N-oxide, or (c) a quaternary ammonium or pyridinium group at the pertinent position. The above molecule-designing strategy proved to be particularly prolific in designing inhibitors of OSC, being its reaction mechanism characterized by the consecutive formation of a number of carbocationic HEIs. Dozens of inhibitors have been synthesized during the last thirty years: (i) azadecalin and azasqualene derivatives [14], (ii) Ro 48-8071 and related benzophenone derivatives designed by Roche [7,15] and AstraZeneca groups [16], (iii) pyridinium ion based inhibitors [9,10,17], (iv) umbelliferone derivatives [18,19], (v) sulfur-containing analogues [20], and others like BIBX 79 [21] (Fig. 1). 


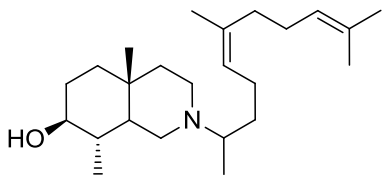

i) azadecaline

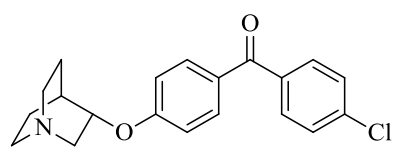

ii) AstraZeneca compound

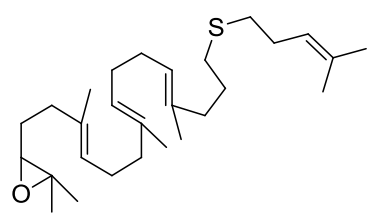

v) sulfur containing analogues

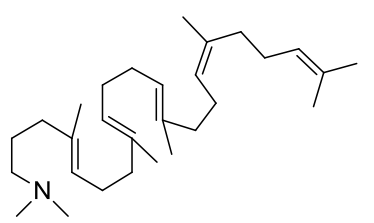

i) azasqualene

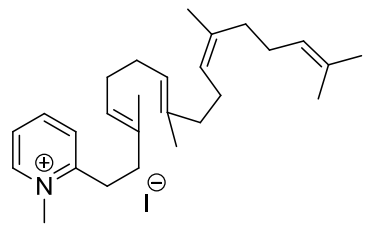

iii) pyridinium ion based inhibitor

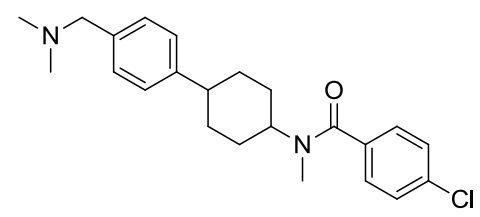

vi) $\mathrm{BIBX} 79$

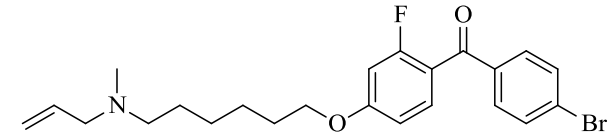

ii) Ro $48-8071$

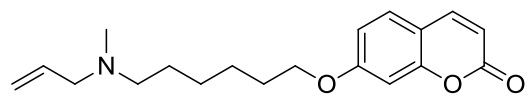

iv) umbelliferone derivatives

Figure 1. Representative inhibitors of oxidosqualene cyclases (OSC).

In continuation of our previous work on the development of inhibitors of oxidosqualene cyclases from various organisms $[12,18,19]$ and other enzymes in ergosterol [22] and cholesterol biosynthesis $[23,24,25]$ we describe here a new chemotype of oxidosqualene cyclase inhibitors that was designed with the following rationale: in order to achieve high affinity to the enzymes, we introduced a homochiral equivalent of the rings $\mathrm{C}$ and $\mathrm{D}$ of sterols and the sterol side chain by using Grundmann's ketone (1) [26] as a building block. To this bicyclic scaffold we attached an aminopropyl chain, ending up with secosteroid-like molecules, in which the protonable nitrogen might mimic two of the early cationic HEIs of the cyclization cascade. Through free rotation of the aminopropyl chain the protonated amino group is able to occupy the position of the first occurring HEI at C-2 of the squalene chain (A; representing pro-C4 of the emerging sterol) as well as that of the pro-C10 HEI (B) (Figure 2). 


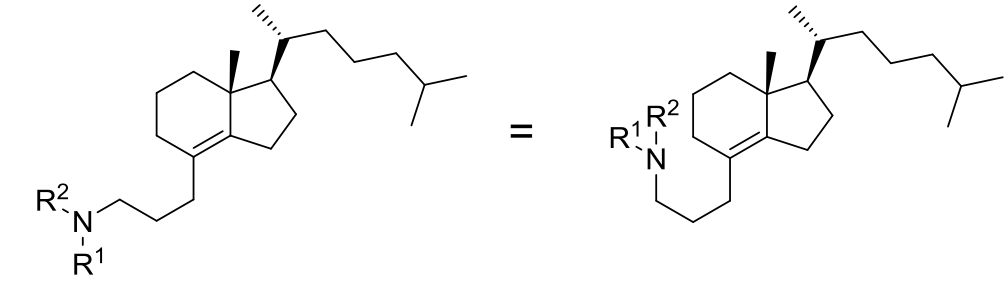

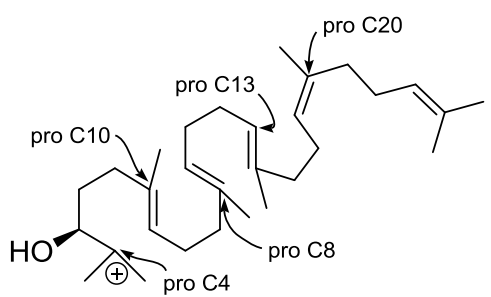

A

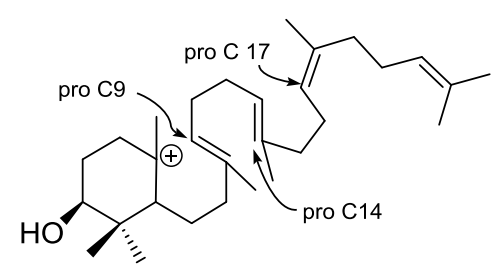

B

Figure 2. Two rotamers of the target compounds (top row), the pro-C4 HEI (A) and the proC10 HEI (B) of lanosterol biosynthesis (bottom row).

The newly designed molecules were assayed on five different OSCs, with the aim of identifying lead molecules for the development of new drugs. All the enzymes, namely lanosterol synthases from Saccharomyces cerevisiae, Pneumocystis carinii, Trypanosoma cruzi, and Homo sapiens, as well as the cycloartenol synthase from Arabidopsis thaliana, were expressed in an ERG7deficient yeast (Saccharomyces cerevisiae) strain [27]. Cycloartenol synthase has been included in the present study in order to ascertain if the critical amino acid differences between lanosterol and cycloartenol synthases would influence their sensitivity to our inhibitors [28].

In order to confirm activities of the inhibitors in a cellular system, selected compounds were assayed for their inhibition of total cholesterol biosynthesis in a human cell line [24].

Some of our new molecules proved to be highly effective and specific, and offer interesting clues to the development of new OSC inhibitors, especially as antiparasitic drugs.

\section{Results and Discussion}

\subsection{Chemistry}

Grundmann's ketone (also named Windaus ketone; 1) [26] was obtained in high yield by ozonolysis of cholecalciferol (vitamin $\mathrm{D}_{3}$ ), but by using a novel workup procedure (treatment of the ozonolysis mixture with water, followed by extraction with pentane). In this manner the well-documented epimerization of $\mathbf{1}$ at C-3a [29] could be avoided. The ketone was reacted with cyclopropylmagnesium bromide to give the tertiary alcohol 2. NMR and GC analysis of 
the crude product revealed that a mixture of epimers (putatively at C-3a and/or C-4) was formed. Since the stereocenters at both C-3a and C-4 were to be destroyed in the subsequent step, intermediate $\mathbf{2}$ was purified only superficially over a short silica column. Crude $\mathbf{2}$ was treated with hydrogen bromide in glacial acetic acid [30] to give the bromopropyl derivative $\mathbf{3}$ in high yield. The underlying homoallylic rearrangement led to a product with an endocyclic tetrasubstituted olefin, namely a product with only three, moreover configurationally stable asymmetric centers. Finally, reaction of $\mathbf{3}$ with primary and cyclic as well as acyclic secondary amines gave the desired aminopropylindene derivatives 4 - 7. The piperidine substituent was selected since it might additionally mimic the ring A of the sterol, the $\mathrm{N}$-allyl$\mathrm{N}$-methyl motif was selected, since it can be found in the benzophenone-type OSC inhibitor Ro-48-8071 (Fig. 1), which had recently been co-crystallized with human OSC and shown to bind to the enzyme in a manner like the pro-C-4 HEI A (Figure 2) does [5]. Since carbocationic HEIs can also be mimicked by tertiary amine $N$-oxides [31] and $N$ alkylpyridinium salts [9], $N$-oxide 9 was prepared by oxidation of tertiary amine $\mathbf{6}$ with metachloroperbenzoic acid (MCPBA), and pyridinium salt $\mathbf{8}$ by reaction of the intermediate $\mathbf{3}$ with pyridine.

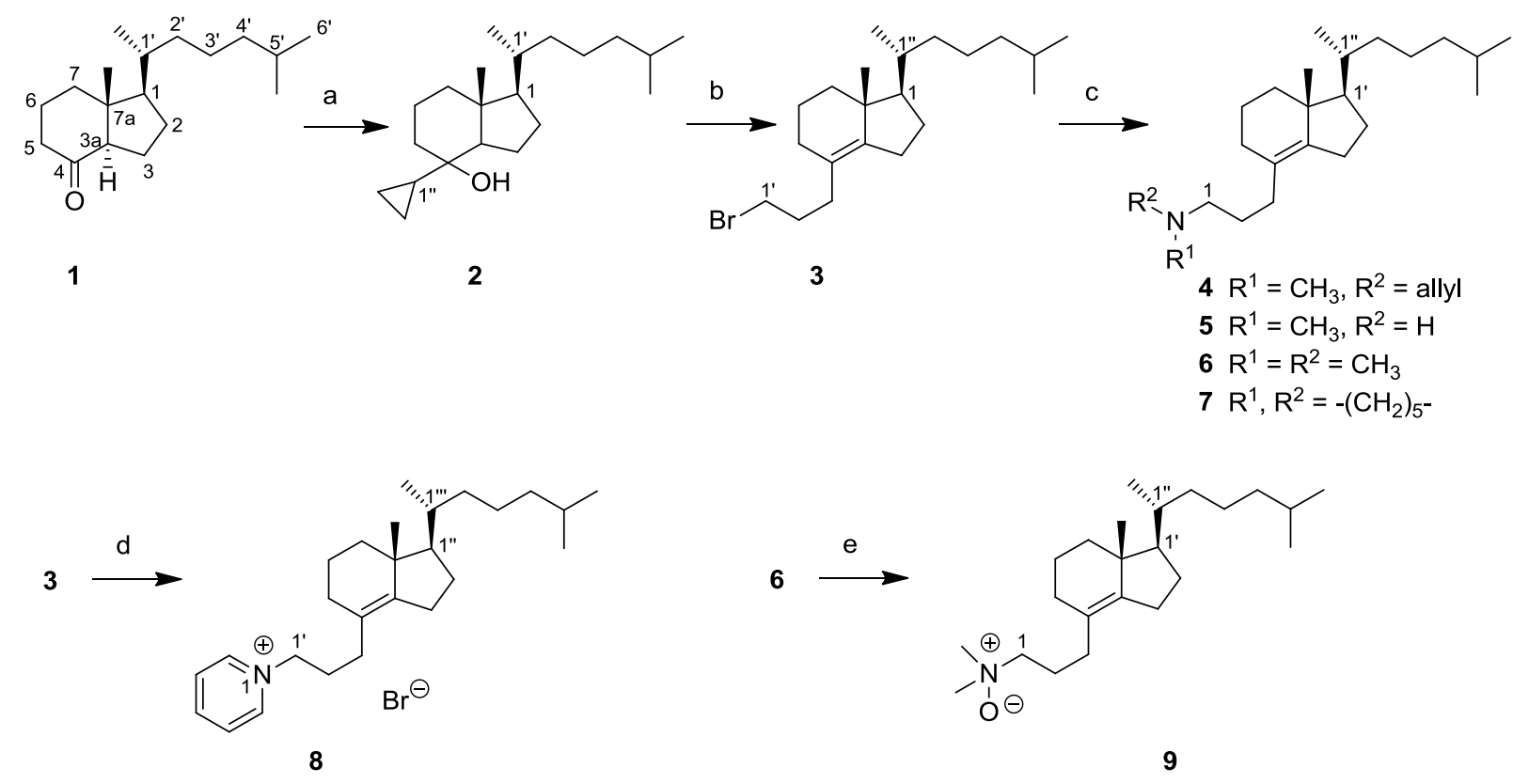

Scheme 1. Reagents and conditions: (a) cyclopropylmagnesium bromide, THF, reflux, $3.5 \mathrm{~h}$, (69\%); (b) $\mathrm{HBr}$ in acetic acid, $10^{\circ} \mathrm{C}, 30 \mathrm{~min}(82 \%)$; (c) aliphatic amine, acetonitrile, 20 or 40 ${ }^{\circ} \mathrm{C}, 72 \mathrm{~h}\left(56\right.$ - 98\%); (d) pyridine, reflux, $1 \mathrm{~h}$ (82\%); (e) MCPBA, chloroform, $0{ }^{\circ} \mathrm{C}, 30 \mathrm{~min}$ $(82 \%)$. 


\subsection{Effect of inhibitors on OSCs from different organisms}

Activity of the compounds as inhibitors of OSC was tested by incubating homogenates prepared from cell cultures of different recombinant yeast strains with radiolabelled 2,3oxidosqualene in the presence of increasing inhibitor concentrations. A comparative determination of OSC inhibitory activity of the compounds on the recombinant enzymes revealed that compound $\mathbf{5}$, exclusively bearing a secondary amino group in the side-chain, was inactive on any OSC under investigation, while the remaining compounds showed both a strong structure-linked dependence and, other than the reference inhibitor Ro 48-8071, considerable differences in susceptibility among the enzymes from different organisms (Table 1).

OSC from $P$. carinii revealed to be significantly inhibited only by $\mathbf{4}$, a molecule which on the other hand displayed comparably high activity on all assayed enzymes ( $\mathrm{IC}_{50}$ range: 0.6-1.5 $\mu \mathrm{M})$.

Among the target enzymes, cycloartenol synthase from the plant $A$. thaliana appeared to be the most sensitive to the inhibitors, with $\mathrm{IC}_{50}$ values $\leq 1 \mu \mathrm{M}$ for five of the six compounds assayed (Table 1). Inhibitors, which bear bulky piperidine and pyridinium rings show the most distinct selectivity for the cycloartenol synthase of $A$. thaliana. The oxidosqualene cyclases of the other species tested are more sensitive to inhibitors with small substituents at the nitrogen, and show no or only week inhibitory effects if bulky residues were chosen. Interestingly, similar organism-dependent differences were observed in a previous study of ours [19], in which a series of aminoalkyl umbelliferone derivatives were assayed on the same set of OSCs as in the present study. In that study, the most dramatic difference between plant and other OSCs was observed with a compound bearing a morpholine ring, which proved to be highly effective on the cyclase from A. thaliana, while resulted almost ineffective against the other OSCs. Pyridinium salt $\mathbf{8}$ showed negligible inhibition of T. cruzi OSC, what is in contrast to previous reports claiming that the significant antitrypanosomal activities of simple $N$-terpenyl pyridinium salts can be attributed to an inhibition of $T$. cruzi OSC [10]. Comparison of the inhibitory effects of the $N, N$-dimethylamino compound $\mathbf{6}$ and the corresponding $\mathrm{N}$-oxide 9 revealed that the tertiary amine showed higher activities on all OSCs, but parallels in species selectivity are evident. This suggests that steric parameters might be crucial for species selectivity in this new chemotype of OSC inhibitors. Most interestingly, both the $\mathrm{N}, \mathrm{N}$-dimethylamino compound $\mathbf{6}$ and the $\mathrm{N}$-oxide $\mathbf{9}$ show strong inhibition of T. cruzi OSC. In contrast to the reference inhibitor Ro 48-8071, however, these 
two compounds show considerable selectivity with respect to human OSC (factors $\geq 7$ ), a property that is worth deeply exploring in designing new anti-trypanosomal agents.

Table 1. Effect of inhibitors on oxidosqualene cyclase activity of homogenates prepared from yeast recombinant strains SMY8 expressing S. cerevisiae, P. carinii, T. cruzi, A. thaliana and H. sapiens OSCs.

\begin{tabular}{|c|c|c|c|c|c|}
\hline \multirow{3}{*}{ Compound } & \multicolumn{5}{|l|}{$\mathrm{IC}_{50}(\mu \mathrm{M})^{\mathrm{a}}$} \\
\hline & $\mathrm{OSC}^{\mathrm{b}}$ & $\mathrm{OSC}^{\mathrm{b}}$ & $\mathrm{OSC}^{\mathrm{b}}$ & $\mathrm{OSC}^{\mathrm{c}}$ & $\mathrm{OSC}^{\mathrm{b}}$ \\
\hline & S. cerevisiae & P. carinii & T. cruzi & A. thaliana & H. sapiens \\
\hline 4 & 1.5 & 0.9 & 0.8 & 0.6 & 1.0 \\
\hline 5 & $>20$ & $>20$ & $>20$ & $>20$ & $>20$ \\
\hline 6 & 1.3 & 13 & 0.6 & 0.3 & 4.5 \\
\hline 7 & 2.1 & 17 & $>20$ & 0.5 & 11.9 \\
\hline 8 & 4.2 & 11 & $>20$ & 0.2 & 12.5 \\
\hline 9 & 2.5 & 15 & 3 & 1.3 & $>20$ \\
\hline $\begin{array}{l}\text { Ro 48- } \\
\text { 8071 }^{\text {d }}\end{array}$ & 0.21 & 0.34 & 0.90 & 1.75 & 0.17 \\
\hline
\end{tabular}

\footnotetext{
${ }^{\text {a }}$ Values are the means of two separate experiments, each one carried out in duplicate. The maximum deviations from the mean were less than $10 \%$.

${ }^{\mathrm{b}}$ Lanosterol synthase

${ }^{\mathrm{c}}$ Cycloartenol synthase

${ }^{\mathrm{d}}$ From ref. [12]
}

\subsubsection{Cytotoxic activity}

A first screening for cytotoxic activities of the compounds was performed in a MTT assay according to the method of Mosmann [32] on human leukaemia HL-60 cells. Cisplatin was used as reference. The results are shown in Table 2 . Significant cytotoxicity $\left(\mathrm{IC}_{50}<10 \mu \mathrm{M}\right)$ was recorded only for the pyridinium compound $\mathbf{8}$. Probably, this can be attributed to the detergent-like properties of this compound. $\mathrm{N}$-Oxide 9 showed moderate cytotoxicity $\left(\mathrm{IC}_{50}=\right.$ $20 \mu \mathrm{M}$ ), what makes it less attractive for further drug development compared to its tertiary 
amino analogue 6, which is, like all other primary and secondary amines investigated here, devoid of cytotoxicity. In contrast, reference OSC inhibitor Ro 48-8071 showed noteworthy cytotoxicity $\left(\mathrm{IC}_{50}=8 \mu \mathrm{M}\right.$ ). BIBX 79 (Fig. 1), another prominent OSC inhibitor, showed no significant cytotoxicity. This shows, that the inhibition of cholesterol biosynthesis is not necessarily correlating with the cytotoxicity of the inhibitors.

Table 2. Cytotoxic activities of investigated compounds against HL-60 cells determined by MTT assay.

\begin{tabular}{ll}
\hline Compound & $\mathrm{IC}_{50}[\mu \mathrm{M}]$ \\
\hline Cisplatin & 5 \\
Ro 48-8071 & 8 \\
BIBX 79 & $>\mathbf{5 0}$ \\
$\mathbf{4}$ & $>100$ \\
$\mathbf{5}$ & $>100$ \\
$\mathbf{6}$ & $>100$ \\
$\mathbf{7}$ & $>100$ \\
$\mathbf{8}$ & 3.5 \\
$\mathbf{9}$ & 20 \\
\hline
\end{tabular}

\subsubsection{Assay for inhibition of cholesterol biosynthesis in cells}

Compounds 4 and 6, which showed significant inhibition of human OSC in the in vitro screenings (Table 1), were subjected to a whole cell assay on human HL-60 cells in order to investigate their activity at the cellular level. This assay is based on a method described by us previously [24]. The inhibitors were tested in triplicates at a concentration of $1 \mu \mathrm{M}$.

Incubation in the presence of $2-{ }^{13} \mathrm{C}$-acetate leads to the incorporation of ${ }^{13} \mathrm{C}$ atoms into the cholesterol molecules biosynthesized during the incubation period, and allows us to distinguish newly synthesised cholesterol from unlabelled matrix cholesterol that was present in the cells before incubation, by GC-MS. At a fixed concentration of $1 \mu \mathrm{M} 4$ and 6 led to a decrease of overall cholesterol biosynthesis of $>90 \%$ compared to untreated control samples. At the same concentration Ro 48-8071 led to a decrease of $>90 \%$, for BIBX 79 a reduction of $60 \%$ was recorded. 


\section{Conclusion}

This paper describes the design, synthesis, and biological evaluation of a series of aminopropylindenes as a new chemotype of oxidosqualene cyclase (OSC) inhibitors. Our concept included the design of inhibitors which contain typical structural elements of sterols (rings $\mathrm{C}+\mathrm{D}$ and the lipophilic side chain), introduced by utilizing Grundmann's ketone as a building block, as well as a protonable or cationic functional group at a position where high energy intermediates of the OSC-catalyzed cyclization reaction occur. The compounds were tested in vitro for inhibition of five different oxidosqualene cyclases, among which four lanosterol synthases (from Saccharomyces cerevisiae, Trypanosoma cruzi, Pneumocystis carinii and Homo sapiens), and one cycloartenol synthase (from Arabidopsis thaliana). The screening results of this first, relatively small collection of inhibitors gave first insights into structure-activity-relationships, showing that the size and charge of the side chain have significant impact on activity, selectivity, and cytotoxicity of the compounds. The lack of cytotoxicity of the tertiary amines 4-7 is remarkable.

In a whole cell assay on a human cell line compounds $\mathbf{4}$ and $\mathbf{6}$ showed strong inhibition of total cholesterol biosynthesis, indicating that this class of inhibitors has proper physicochemical properties for being active in living cells.

The concept of combining a significant partial structure of the steroid backbone with functional groups which are able to mimic cationic high energy intermediates, is promising for further evaluation.

\section{Experimental}

\subsection{Chemistry}

Ozonolyses were performed on a Fisher Scientific 502 Ozon Generator (Fisher Scientific, Schwerte, Germany). Melting points were determined by open tube capillary method on a Büchi melting point B-450 apparatus and are uncorrected. IR spectra were obtained on a Perkin Elmer FT-IR: Paragon 1000 spectrometer. NMR spectra were recorded on Jeol JNMRGX $400(400 \mathrm{MHz})$ and Jeol JNMR-GX $500(500 \mathrm{MHz})$ spectrometers with tetramethylsilane as an internal standard. $J$ values are given in Hz. Mass spectra (MS) were run by chemical impact (CI; reactant gas: methane) on a Hewlett Packard 5989 A mass spectrometer with 
59980 B particle beam LC/MS interface, and by electron impact (EI) at $70 \mathrm{eV}$ on a Jeol JMS GCmate II. Solvents were of HPLC grade or p.a. grade, if not they were distilled before use. All chemicals were purchased from Sigma Aldrich (Schnelldorf, Germany) and Acros Organics (Geel, Belgium). Reactions were monitored by thin-layer chromatography (TLC) using pre-coated plastic sheets POLYGRAM SIL G/UV254 from Macherey-Nagel (Düren, Germany). Merck silica gel 60 was used as stationary phase for flash column chromatography (FCC).

The OSC substrate, 2,3-oxidosqualene (OS), was prepared as previously described [33]. Labelled $\left[{ }^{14} \mathrm{C}\right]-(3 \mathrm{~S}) 2,3$-oxidosqualene was obtained through biological synthesis by incubating pig liver $\mathrm{S}_{10}$ supernatant with $\mathrm{R}, \mathrm{S}\left[2-{ }^{14} \mathrm{C}\right] \mathrm{mevalonic}$ acid $(1 \mu \mathrm{Ci}, 55 \mathrm{mCi} / \mathrm{mmol}$, 2.04 GBq/mmol) (Amersham Pharmacia Biotech, U.K), in the presence of OSC inhibitor U14266A [34].

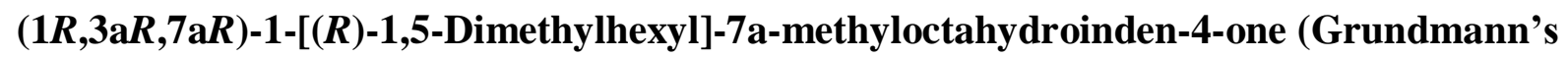
ketone; 1)

A solution of cholecalciferol $(5.00 \mathrm{~g}, 13.0 \mathrm{mmol})$ in methanol $(100 \mathrm{~mL})$ was cooled to -30 to $40{ }^{\circ} \mathrm{C}$ and ozone was bubbled through the solution $(60 \mathrm{~L} / \mathrm{h})$ for 30 minutes. The solution was treated with $50 \mathrm{~mL}$ water, concentrated under reduced pressure to $80 \mathrm{~mL}$ volume, and extracted with pentane $(3 \times 100 \mathrm{~mL})$. The combined organic layers were dried over magnesium sulphate and concentrated under reduced pressure. The crude product was purified by FCC (hexane:ethyl acetate 10:1) to yield $3.35 \mathrm{~g}(97 \%)$ of Grundmann's ketone as a colourless oil. $[\alpha]_{D}^{20}=+42.1 ;$ IR $(\mathrm{NaCl}): \tilde{v}=2958 \mathrm{~cm}^{-1}, 1677,1418,1245,1209,1144,961$; ${ }^{1} \mathrm{H} \mathrm{NMR}\left(\mathrm{CDCl}_{3}\right): \delta=2.42 \mathrm{ppm}\left(\mathrm{dd}, J_{l}=11.8, J_{2}=7.5 \mathrm{~Hz}, 1 \mathrm{H}, 3 \mathrm{a}-\mathrm{H}\right), 2.29-2.18(\mathrm{~m}, 2 \mathrm{H}, 5-$ H), 2.12 (m, 1 H, 7-H), 2.00 (m, 1 H, 6-H), 1.95-1.85 (m, 2 H, 3-H, 6-H), 1.73 (m, 1 H, 2-H), 1.61-1.28 (m, 8 H, 1-H, 2-H, 3-H, 7-H, 1'-H, 2'-H, 3'-H, 5'-H), 1.18-1.00 (m, 4 H, 2'-H, 3'H, 4'-H), 0.95 (d, J = 6.6 Hz, 3 H, 1'- $-\mathrm{CH}_{3}$ ), 0.86 (d, J = 6.7 Hz, 3 H, 6'-H), 0.85 (d, J = 6.6 $\left.\mathrm{Hz}, 3 \mathrm{H}, 5{ }^{\prime}-\mathrm{CH}_{3}\right), 0.65$ (s, $\left.3 \mathrm{H}, 7 \mathrm{a}-\mathrm{CH}_{3}\right) ;{ }^{13} \mathrm{C} \mathrm{NMR}\left(\mathrm{CDCl}_{3}\right): \delta=212.3 \mathrm{ppm}, 62.0,56.8,49.9$, 41.0, 39.4, 39.0, 35.9, 35.5, 28.0, 27.5, 24.1, 23.7, 22.8, 22.5, 19.0, 18.7, 12.5; MS (CI): $\mathrm{m} / \mathrm{z}$ $(\%)=265(64)[\mathrm{M}+\mathrm{H}]^{+}, 247(100) ; \mathrm{MS}(\mathrm{EI}, 70 \mathrm{eV}): \mathrm{m} / z(\%)=264(19)[\mathrm{M}]^{+} ; 125$ (100), 111 (61); HRMS (EI, $70 \mathrm{eV}$ ): $\mathrm{m} / z=264.2495[\mathrm{M}]^{+}$, calcd for $\mathrm{C}_{22} \mathrm{H}_{41} \mathrm{~N}: 264.2453$. 
Under nitrogen, a solution of $800 \mathrm{mg}(3.03 \mathrm{mmol})$ Grundmann's ketone (1) in $20 \mathrm{~mL}$ anhydrous THF was added dropwise to $9.0 \mathrm{~mL}$ of solution of cyclopropylmagnesium bromide (0.5 $\mathrm{M}$ in THF; $4.5 \mathrm{mmol}$ ) with stirring, and the mixture was refluxed for $3.5 \mathrm{~h}$. After cooling to ambient temperature, the mixture was poured into ice-water $(20 \mathrm{~mL})$, and solid ammonium chloride is added with stirring until the precipitate dissolved. The mixture was extracted with diethyl ether ( $3 \times 20 \mathrm{~mL})$, and the combined organic layers were dried over magnesium sulphate. The oily residue was purified by FSC (cyclohexane:ethyl acetate 20:1) to give crude tertiary alcohol 2. (640 mg; about 69\%; mixture of isomers). This product was dissolved in glacial acetic acid $(2 \mathrm{~mL})$ and $0.30 \mathrm{~mL}$ of a solution of $\mathrm{HBr}$ in glacial acetic acid (40\%) was added. The reaction mixture was stirred under a nitrogen atmosphere for $30 \mathrm{~min}$ and then extracted with diethyl ether $(3 \times 20 \mathrm{~mL})$. The combined organic layers were dried over magnesium sulphate and concentrated under reduced pressure. The crude product was purified by FCC (heptane) to yield $632 \mathrm{mg}$ (82\% calculated on crude $2 ; 56 \%$ over both steps ) of 3 as colourless oil. $[\alpha]_{D}^{20}=+48.2$. IR $(\mathrm{NaCl}): \tilde{\mathrm{v}}=2953 \mathrm{~cm}^{-1}, 2858,1465,1368,1247 ;{ }^{1} \mathrm{H}$ NMR $\left(\mathrm{CDCl}_{3}\right): \delta=3.36$ ppm (m, 2 H, 3'-H), 2.33-2.18 (m, 2 H, 3-H), 2.14-2.07 (m, 1 H, 2H), 2.00-1.74 (m, 7 H, 1'-H, 2-H, 2'-H, 5'-H, 7-H), 1.73-1.61 (m, 2 H, 6-H), 1.55-1.48 (m, 2 H, 1' '-H, 5' '-H), 1.40-1.02 (m, 9 H, 1-H, 2' '-H, 3' '-H, 4' '-H, 5-H, 7-H), 0.94 (d, J = 6.6 Hz, $3 \mathrm{H}, 1$ ' '-CH $\left.\mathrm{CH}_{3}\right), 0.87$ (d, J = 6.6 Hz, $3 \mathrm{H}, 5$ ' '- $\left.\mathrm{CH}_{3}\right), 0.86$ (d, J = 6.6 Hz, $3 \mathrm{H}, 6$ ' '-H), 0.85 (s, 3 $\left.\mathrm{H}, 7 \mathrm{a}-\mathrm{CH}_{3}\right) ;{ }^{13} \mathrm{C} \mathrm{NMR}\left(\mathrm{CDCl}_{3}\right): \delta=144.1 \mathrm{ppm}, 124.5,56.4,43.1,39.6,37.4,36.0,34.7,33.8$, $32.1,31.4,28.0$ (2 C), 27.1, 25.3, 23.8, 22.8, 22.6, 19.5, 19.0, 18.4; MS (CI): $m / z(\%)=371$ (34) $[\mathrm{M}+\mathrm{H}]^{+}, 369$ (40) $[\mathrm{M}+\mathrm{H}]^{+}, 355$ (4), 353 (2), 257 (61), 255 (50), 127 (100); MS (EI, 70 $\mathrm{eV}): m / z(\%)=370(2)[\mathrm{M}]^{+}, 368(4)[\mathrm{M}]^{+}, 355$ (8), 353 (10), 257 (90), 255 (100); Anal. Calcd for $\mathrm{C}_{21} \mathrm{H}_{37} \mathrm{Br}(\%)$ : C 68.28, H 10.10. Found C 68.40, H 10.23.

\section{$N$-Allyl- $N$-methyl-\{3-[(1R,7aR)-1-[(R)-1,5-dimethylhexyl]-7a-methyl-2,3,5,6,7,7a- hexyhydro-1H-inden-4-yl]-propyl \}amine (4)}

To a solution of bromo compound $3(0.18 \mathrm{~g}, 0.49 \mathrm{mmol})$ in $5.0 \mathrm{~mL}$ acetonitrile and $N$ allylmethylamine $(3.0 \mathrm{~mL}, 1.8 \mathrm{mmol})$ was added, and the mixture was stirred at room temperature for $72 \mathrm{~h}$ under a nitrogen atmosphere. Then, a $\mathrm{NaHCO}_{3}$ solution $(20 \mathrm{~mL}, 5 \%)$ was added, and the mixture was extracted with methylene chloride $(3 \times 20 \mathrm{~mL})$. The combined organic layers were dried over sodium sulphate and concentrated under reduced pressure. The crude product was purified by FCC (heptane:ethyl acetate:EDMA ( $N$-ethyl$N, N$-dimethylamine) $8: 2: 0.1)$ to yield $98 \mathrm{mg}(56 \%)$ of $\mathbf{4}$ as yellow oil. $[\alpha]_{D}^{20}=+46.9$. IR $(\mathrm{NaCl}): \tilde{v}=3075 \mathrm{~cm}^{-1}, 2950,2867,2784,1835,1733,1643,1463,1367,995 ;{ }^{1} \mathrm{H}$ NMR 
$\left(\mathrm{CDCl}_{3}\right): \delta=5.91-5.81 \mathrm{ppm}\left(\mathrm{m}, 1 \mathrm{H}, 2^{\prime}{ }^{\prime}{ }^{-\mathrm{H}}\right), 5.19-5.14\left(\mathrm{~m}, 2 \mathrm{H}, 3^{\prime}{ }^{\prime}{ }^{-}-\mathrm{H}\right), 3.00(\mathrm{~d}, J=6.6 \mathrm{~Hz}$, $2 \mathrm{H}, 1$ ' ' '-H), 2.33-2.23 (m, 4 H, 1-H, 3'-H), 2.21 (s, 3 H, $\left.N-\mathrm{CH}_{3}\right), 1.98-1.80$ (m, $6 \mathrm{H}, 2$ '-H, $3-$ H, 5'-H, 7'-H), 1.71-1.61 (m, 2 H, 6'-H), 1.57-1.49 (m, 3 H, 2-H, 5' '-H), 1.44-1.31 (m, 4 H, 1''-H, 2'-H, 2'”-H, 3'”-H), 1.19-1.05 (m, 6 H, 1'-H, 2' '-H, 3'”-H, 4'”-H, 7'-H), 0.94 (d, J = $6.6 \mathrm{~Hz}, 3 \mathrm{H}, 1$ ' '-CH 3$), 0.87\left(\mathrm{~d}, J=6.6 \mathrm{~Hz}, 3 \mathrm{H}, 5\right.$ ' '- $\left.\mathrm{CH}_{3}\right) 0.86$ (d, J = 6.6 Hz, $3 \mathrm{H}, 6$ ' '-H), $0.84\left(\mathrm{~s}, 3 \mathrm{H}, 7 \mathrm{a}{ }^{-}-\mathrm{CH}_{3}\right) ;{ }^{13} \mathrm{C} \mathrm{NMR}\left(\mathrm{CDCl}_{3}\right): \delta=142.7 \mathrm{ppm}, 135.8,125.9,117.5,61.0,57.1$, 56.4, 43.0, 42.0, 39.6, 37.5, 36.0, 34.8, 31.3, 28.0, 27.9, 27.1, 25.6, 25.2, 23.8, 22.8, 22.6, 19.6, 19.0, 18.4; MS (CI): m/z (\%) = 360 (100) $[\mathrm{M}+\mathrm{H}]^{+}, 358$ (12), 344 (4), 175 (6), 110 (83); MS (EI, $70 \mathrm{eV}): m / z(\%)=359$ (6) [M] $]^{+}, 344$ (2), 330 (4), 246 (4), 175 (6), 147 (6), 133 (6), 110 (100); Anal. Calcd for $\mathrm{C}_{25} \mathrm{H}_{45} \mathrm{~N}(\%)$ : C 83.49, H 12.61, N, 3.89. Found C 83.35, H 12.70, N 3.89 .

$N$-Methyl-\{3-[1R,7aR)-1-[(R)-1,5-dimethylhexyl]-7a-methyl-2,3,5,6,7,7a-hexahydro-1Hinden-4-yl]-propyl \}amine (5)

Bomo compound $3(0.20 \mathrm{~g}, 0.54 \mathrm{mmol})$ was dissolved in a $2 \mathrm{M}$ solution of methylamine in THF (2.7 mL, $5.4 \mathrm{mmol})$, and the solution was stirred at $40{ }^{\circ} \mathrm{C}$ under a nitrogen atmosphere for $72 \mathrm{~h}$. Then, a $\mathrm{NaHCO}_{3}$ solution $(20 \mathrm{~mL}, 5 \%)$ was added and the mixture was extracted with methylene chloride $(3 \times 20 \mathrm{~mL})$. The combined organic layers were dried over sodium sulphate and concentrated under reduced pressure. The crude product was purified by FCC (heptane:ethyl acetate:EDMA 8:2:0.1) to yield $0.12 \mathrm{~g}(70 \%)$ of 5 as yellow oil. $[\alpha]_{D}^{20}=+66.4$. IR $(\mathrm{NaCl}): \tilde{v}=3333 \mathrm{~cm}^{-1}, 2952,2869,1465,1367 ;{ }^{1} \mathrm{H}$ NMR $\left(\mathrm{CDCl}_{3}\right): \delta=2.34-2.17 \mathrm{ppm}(\mathrm{m}$, 7 H, 1-H, 2-H, $N-\mathrm{CH}_{3}$, ) , 1.96-1.78 (m, 6 H, 3-H, 3'-H, 5'-H, 7'-H), 1.71-1.61 (m, 2 H, 6'-H), 1.60-1.31 (m, 7 H, 1'’-H, 2'-H, 2' '-H, 3'-H, 3'”-H, 5' -H), 1.22-1.20 (m, 6 H, 1'-H, 2'”-H,

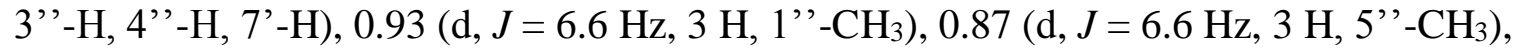
$0.86(\mathrm{~d}, J=6.6 \mathrm{~Hz}, 3 \mathrm{H}, 6$ ' $-\mathrm{H}), 0.84\left(\mathrm{~s}, 3 \mathrm{H}, 7 \mathrm{a}{ }^{\prime}-\mathrm{CH}_{3}\right) ;{ }^{13} \mathrm{C} \mathrm{NMR}\left(\mathrm{CDCl}_{3}\right): \delta=142.7 \mathrm{ppm}$, 126.4, 57.6, 56.5, 47.6, 43.0, 41.0, 37.6, 36.0, 34.9, 31.4, 28.1 (2x), 27.2, 25.6, 25.3, 23.9, 22.9, 22.7, 19.6, 19.1, 18.5; MS (CI): $m / z(\%)=320(100)[\mathrm{M}+\mathrm{H}]^{+}, 314$ (14), 279 (19), 261 (6), 187 (8), 167 (14), 149 (52), 113 (38); MS (EI, $70 \mathrm{eV}): \mathrm{m} / z(\%)=319$ (1) [M] ${ }^{+} ; 317$ (2), 273 (2), 247 (2), 175 (6), 149 (19), 85 (41), 59 (100); HRMS (EI, $70 \mathrm{eV}$ ): $\mathrm{m} / z=319.3259$ $[\mathrm{M}]^{+}$, calcd for $\mathrm{C}_{22} \mathrm{H}_{41} \mathrm{~N}: 319.3239$.

$N, N$-Dimethyl-\{3-[1R,7aR)-1-[(R)-1,5-dimethylhexyl]-7a-methyl-2,3,5,6,7,7a-hexahydro$1 H$-inden-4-yl]-propyl $\}$ amine (6) 
Bromo compound $3(0.15 \mathrm{~g}, 0.41 \mathrm{mmol})$ was dissolved in a $2 \mathrm{M}$ solution of dimethylamine in THF (4.0 mL, $8.0 \mathrm{mmol}$ ), and the solution was stirred at room temperature under a nitrogen atmosphere for $24 \mathrm{~h}$. Then, a $\mathrm{NaHCO}_{3}$ solution $(20 \mathrm{~mL}, 5 \%)$ was added, and the mixture was extracted with methylene chloride $(3 \times 20 \mathrm{~mL})$. The combined organic layers were dried over sodium sulphate and concentrated under reduced pressure. The crude product was purified by FCC (heptane:ethyl acetate:EDMA 8:2:0.1) to yield $96 \mathrm{mg}(70 \%)$ of 6 as yellow oil. $[\alpha]_{D}^{20}=$ +25.6. IR $(\mathrm{NaCl}): \tilde{v}=2935 \mathrm{~cm}^{-1}, 2812,1464,1368,1265,1042,812 ;{ }^{1} \mathrm{H} \mathrm{NMR}\left(\mathrm{CDCl}_{3}\right): \delta=$ 2.24-2.18 ppm (m, 10 H, 1-H, 2-H, $\left.N\left(\mathrm{CH}_{3}\right)_{2}\right), 1.98-1.81$ (m, 6 H, 3-H, 3'-H, 5'-H, 7'-H), 1.71-1.62 (m, 2 H, 6'-H), 1.58-1.31 (m, 7 H, 1' '-H, 2'-H, 2'’-H, 3'-H, 3'”-H, 5' -H), 1.241.02 (m, 6 H, 1'-H, 2'’-H, 3' '-H, 4' '-H, 7'-H), 0.94 (d, J = 6.6 Hz, 3 H, 1' '-CH $\mathrm{CH}_{3}, 0.87$ (d, J = $6.6 \mathrm{~Hz}, 3 \mathrm{H}, 5$ ' $\left.-\mathrm{CH}_{3}\right), 0.86\left(\mathrm{~d}, J=6.6 \mathrm{~Hz}, 3 \mathrm{H}, 6\right.$ ' '-H), 0.84 (s, $3 \mathrm{H}, 7 \mathrm{a}$ '- $\left.\mathrm{CH}_{3}\right)$; ${ }^{13} \mathrm{C} \mathrm{NMR}$ $\left(\mathrm{CDCl}_{3}\right): \delta=142.7 \mathrm{ppm}, 126.0,59.8,56.5,45.6,43.0,39.6,37.5,36.0,34.8,31.4,28.0(2 \mathrm{x})$, 27.2, 26.2 25.2, 23.8, 22.8, $22.6(2 \mathrm{C}), 19.6,19.0,18.4 ; \mathrm{MS}(\mathrm{CI}): \mathrm{m} / z(\%)=334(100)$ $[\mathrm{M}+\mathrm{H}]^{+}, 318$ (4), $248(4) ; \mathrm{MS}(\mathrm{EI}, 70 \mathrm{eV}): \mathrm{m} / z(\%)=333$ (5) [M] $]^{+} ; 84$ (51), 58 (100); HRMS (EI, $70 \mathrm{eV}$ ): $\mathrm{m} / z=333.3378[\mathrm{M}]^{+}$, calcd for $\mathrm{C}_{23} \mathrm{H}_{43} \mathrm{~N}: 333.3395$; Anal. Calcd for $\mathrm{C}_{23} \mathrm{H}_{43} \mathrm{~N}$ (\%): C 82.81, H 12.99, N 4.20. Found C 82.63, H 13.27, N 4.17.

\section{$N$-\{3-[1R,7aR)-1-[(R)-1,5-Dimethylhexyl]-7a-methyl-2,3,5,6,7,7a-hexahydro-1H-inden-4- yl]-propyl\}piperidine (7)}

A solution of bromo compound $3(0.15 \mathrm{~g}, 0.41 \mathrm{mmol})$ in piperidine $(0.70 \mathrm{~g}, 8.2 \mathrm{mmol})$ was stirred at room temperature under a nitrogen atmosphere for $3 \mathrm{~d}$. Then, a $\mathrm{NaHCO}_{3}$ solution $(20 \mathrm{~mL}, 5 \%)$ was added, and the mixture was extracted with methylene chloride $(3 \mathrm{x} 20 \mathrm{~mL})$. The combined organic layers were dried over sodium sulphate and concentrated under reduced pressure. The crude product was purified by FCC (heptane:EDMA 10:0.1) to yield $0.15 \mathrm{~g}(98 \%)$ of 7 as yellow oil. $[\alpha]_{D}^{20}=+41.6$. IR $(\mathrm{NaCl}): \tilde{v}=2935 \mathrm{~cm}^{-1}, 2812,1464,1368$, 1265, 1042, 812; ${ }^{1} \mathrm{H}$ NMR $\left(\mathrm{CDCl}_{3}\right): \delta=2.41-2.32$ ppm $(\mathrm{m}, 4 \mathrm{H}, 2-\mathrm{H}, 6-\mathrm{H}), 2.30-2.18(\mathrm{~m}, 2$ H, 1'-H), 1.98-1.90 (m, 4 H, 3'-H, 5' '-H, 7' '-H), 1.89-1.80 (m, 2 H, 3'”-H), 1.76-1.66 (m, 2 H, 6' '-H), 1.65-1.50 (m, 12 H, 2'-H, 2' '-H, 3-H, 4-H, 5-H, 5' '-H, 5' ' '-H), 1.48-1.34 (m, 3 H,

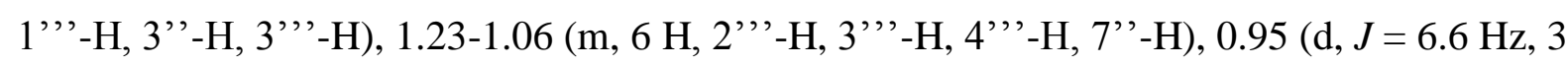

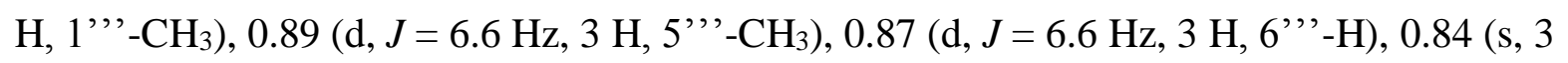
$\left.\mathrm{H}, 7 \mathrm{a}{ }^{\prime}{ }^{-} \mathrm{CH}_{3}\right) ;{ }^{13} \mathrm{C} \mathrm{NMR}\left(\mathrm{CDCl}_{3}\right): \delta=142.7 \mathrm{ppm}, 126.1,59.3,56.5,54.7$ (2x), 43.0, 39.6, 37.5, 36.0, 34.8, 31.5, 28.0 (2x), 27.2, 26.2, 25.2, 24.6 (3C), 23.8, 22.8, 22.6, 19.6, 19.0, 18.4; MS $(\mathrm{CI}): m / z(\%)=374(100)[\mathrm{M}+\mathrm{H}]^{+}, 266(4), 124(10) ; \mathrm{MS}(\mathrm{EI}, 70 \mathrm{eV}): \mathrm{m} / z(\%)=373(12)$ 
$[\mathrm{M}]^{+}$; 124 (26), 111 (12), 98 (100); Anal. Calcd for $\mathrm{C}_{26} \mathrm{H}_{47} \mathrm{~N}$ (\%): C 83.57, H 12.68, N 3.75.

Found C 83.19, H 12.66, N 3.54.

\section{$N-\{3-[1 R, 7 \mathrm{a} R)-1-[(R)-1,5-D i m e t h y l h e x y l]-7 a-m e t h y l-2,3,5,6,7,7 \mathrm{a}-h e x a h y d r o-1 H$-inden-4- yl]-propyl\}pyridinium bromide (8)}

A solution of bromo compound $3(0.18 \mathrm{~g}, 0.49 \mathrm{mmol})$ in pyridine $(0.40 \mathrm{~g}, 5.0 \mathrm{mmol})$ was stirred at reflux for $1 \mathrm{~h}$. Then, the excess of pyridine was distilled off under reduced pressure, and the rsidue was crystallized from heptane to yield $0.18 \mathrm{~g}(82 \%)$ of $\mathbf{8}$ as yellowish solid, Mp. $63{ }^{\circ} \mathrm{C} .[\alpha]_{D}^{20}=+60.2$. IR $(\mathrm{KBr}): \tilde{v}=3416 \mathrm{~cm}^{-1}, 3126,2953,2868,2190,1486,1465$, $1367 ;{ }^{1} \mathrm{H}$ NMR $\left(\mathrm{CDCl}_{3}\right): \delta=9.48 \mathrm{ppm}(\mathrm{d}, J=6.7 \mathrm{~Hz}, 2 \mathrm{H}, 2-\mathrm{H}, 6-\mathrm{H}), 8.55\left(\mathrm{dd}, J_{1}=7.9 \mathrm{~Hz}, J_{2}\right.$ $=1.2 \mathrm{~Hz}, 1 \mathrm{H}, 4-\mathrm{H}), 8.17\left(\mathrm{dd}, J_{l}=7.9 \mathrm{~Hz}, J_{2}=6.7 \mathrm{~Hz}, 2 \mathrm{H}, 3-\mathrm{H}, 5-\mathrm{H}\right), 4.93(\mathrm{t}, J=7.1 \mathrm{~Hz}, 2$ H, 1'-H), 2.15-2.04 (m, 6 H, 2'-H, 3'-H, 5' '-H), 1.97-1.91 (m, 2 H, 7' '-H), 1.90-1.78 (m, 3 H, 2''-H, 3' '-H), 1.69-1.63 (m, 2 H, 6' '-H), 1.52 (tq, $J_{l}=J_{2}=6.6 \mathrm{~Hz}, 1 \mathrm{H}, 5$ ','-H), 1.45-1.25 (m,

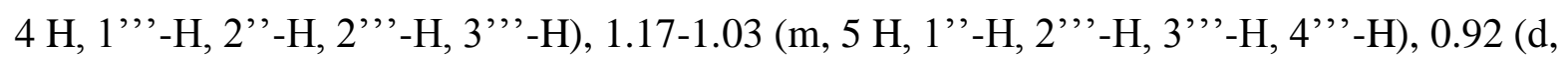
$\left.J=6.6 \mathrm{~Hz}, 3 \mathrm{H}, 1^{\prime \prime}{ }^{-}-\mathrm{CH}_{3}\right), 0.87\left(\mathrm{~d}, J=6.6 \mathrm{~Hz}, 3 \mathrm{H}, 5\right.$ ' ' $\left.{ }_{-} \mathrm{CH}_{3}\right), 0.85(\mathrm{~d}, J=6.6 \mathrm{~Hz}, 3 \mathrm{H}, 6$ ', '$\mathrm{H}), 0.82(\mathrm{~s}, 3 \mathrm{H}, 7 \mathrm{a}$ ',-CH$) ;{ }^{13} \mathrm{C} \mathrm{NMR}\left(\mathrm{CDCl}_{3}\right): \delta=145.2 \mathrm{ppm}(2 \mathrm{C}), 145.1,144.8,128.5$ (2C), 123.6, 62.1, 56.3, 43.5, 39.5, 37.2, 35.9, 34.6, 30.3, 29.9, 28.0, 27.8, 27.0, 25.4, 23.8, 22.8, 22.6, 19.4, 18.9, 18.5; MS (CI): $m / z(\%)=369(100)[\mathrm{M}+\mathrm{H}]^{+}, 333$ (12), 303 (14), 247 (14), 220 (16), 179 (14), 159 (27), 127 (33), 107 (33); MS (EI, 70 eV): m/z (\%) = 368 (20) [M] , 181 (40), 93 (100), 81 (16), 79 (22); Anal. Calcd for $\mathrm{C}_{26} \mathrm{H}_{42} \mathrm{NBr} \times 2 \mathrm{H}_{2} \mathrm{O}(\%)$ : C 64.45, H 9.57, N 2.89. Found C 64.03, H 8.75, N 2.85.

\section{$N, N$-Dimethyl-\{3-[1R,7aR)-1-[(R)-1,5-dimethylhexyl]-7a-methyl-2,3,5,6,7,7a-hexahydro-}

\section{$1 H$-inden-4-yl]-propyl amine- $N$-oxide (9)}

A solution of MCPBA $(0.070 \mathrm{~g}, 0.40 \mathrm{mmol})$ in chloroform $(5 \mathrm{~mL})$ was added dropwise to a stirred solution of tertiary amine $6(0.10 \mathrm{~g}, 0.33 \mathrm{mmol})$ in chloroform $(5 \mathrm{~mL})$. The mixture was stirred at $0{ }^{\circ} \mathrm{C}$ for $30 \mathrm{~min}$, then washed with a saturated $\mathrm{NaHCO}_{3}$ solution $(3 \times 20 \mathrm{~mL})$ and brine $(2 \times 20 \mathrm{~mL})$. The organic layer was dried over sodium sulphate and evaporated under reduced pressure. The residue was purified by FCC (methanol) to yield $86 \mathrm{mg}(82 \%)$ of 9 as colourless viscous oil. $[\alpha]_{D}^{20}=+22.4$. IR $(\mathrm{NaCl}): \tilde{v}=2952 \mathrm{~cm}^{-1}, 1467,1367,957 ;{ }^{1} \mathrm{H}$ NMR (DMSO-d $): \delta=3.01$ ppm (m, $2 \mathrm{H}, 1-\mathrm{H}), 2.96\left(\mathrm{~s}, 6 \mathrm{H}, N\left(\mathrm{CH}_{3}\right)_{2}\right), 2.21-2.16(\mathrm{~m}, 2 \mathrm{H}, 2-$ H), 1.93-1.80 (m, 8 H, 3-H, 3'-H, 5'-H, 7'-H), 1.68-1.60 (m, 2 H, 6'-H), 1.51 (tq, $J_{1}=J_{2}=6.6$ Hz, 1 H, 5' '-H), 1.44-1.23 (m, 4 H, 1' '-H, 2'-H, 2' '-H), 1.18-1.04 (m, 4 H, 1'-H, 2' '-H, 4' 'H), $0.92\left(\mathrm{~d}, J=6.6 \mathrm{~Hz}, 3 \mathrm{H}, 1\right.$ ' ' $\left.-\mathrm{CH}_{3}\right), 0.89-0.83\left(\mathrm{~m}, 11 \mathrm{H}, 7 \mathrm{a}{ }^{-}-\mathrm{CH}_{3}, 3\right.$ ' '-H, 5' $-\mathrm{CH}_{3}, 6$ ' '-H); 
${ }^{13} \mathrm{C}$ NMR (DMSO- $\left.d_{6}\right): \delta=142.4$ ppm, 124.9, 69.9, 58.3, 55.9, 42.5, 38.9, 36.8, 35.3, 34.1, $30.0,27.3,27.1,26.6,24.7,23.1,22.6,22.3,21.3,18.9,18.7,18.2 ; \mathrm{MS}(\mathrm{CI}): \mathrm{m} / z(\%)=350$

(5) $[\mathrm{M}+\mathrm{H}]^{+}, 334$ (100), 320 (48); MS (EI, $\left.70 \mathrm{eV}\right): m / z(\%)=349$ (8) [M] ; 333 (40), 320 (6), 306 (8), 273 (16), 236 (33), 195 (52), 175 (60), 147 (52), 133 (72), 119 (60), 107 (100); HRMS (EI, $70 \mathrm{eV}): \mathrm{m} / z=349.3338[\mathrm{M}]^{+}$, calcd for $\mathrm{C}_{23} \mathrm{H}_{43} \mathrm{NO}: 349.3345$.

\subsection{Strains of S. cerevisiae and cultural conditions}

The recombinant strains of S. cerevisiae, SMY8[pSM61.21] (MATa erg7::HIS3 hem1::TRP1 ura3-52-trp1- $\triangle 63$ LEU2::OSC S. cerevisiae his3-4200 ade2 $\mathrm{Gal}^{+}$) expressing wild-type yeast OSC [36], SMY8[pBJ1.21] (MATa erg7::HIS3 hem1::TRP1 ura3-52 trp1-A63 LEU2::OSC T. cruzi his3-4200 ade2 $\mathrm{Gal}^{+}$) expressing T. cruzi OSC [27], SMY8[pBJ4.21] (MATa erg7::HIS3 hem1::TRP1 ura3-52 trp1-463 LEU2::OSC P. carinii his3-4200 ade2 Gal ${ }^{+}$) expressing P. carinii OSC [27], SMY8[pSM60.21] (MATa erg7::HIS3 hem1::TRP1 ura3-52

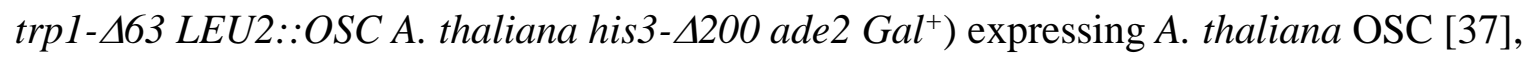
and SMY8[pSOB1.1] (MATa erg7::HIS3 hem1::TRP1 URA3::OSC H. sapiens trp1-463 leu23.112 his3-4200 ade2 $\mathrm{Gal}^{+}$) expressing H. sapiens OSC [38] were used.

Cells of SMY8[pSM61.21], SMY8[pBJ1.21], SMY8[pBJ4.21] and SMY8[pSM60.21] were grown aerobically at $30{ }^{\circ} \mathrm{C}$ to early stationary phase in YPD medium (1\% yeast extract, $2 \%$ peptone, $2 \%$ glucose $)$ supplemented with hemin $(0.013 \mathrm{mg} / \mathrm{mL})$ and ergosterol $(0.02 \mathrm{mg} / \mathrm{mL})$. Hemin is needed in the medium as the SMY8 strains contain a mutation (hem1::TRP1) affecting the heme biosynthesis. The presence of a heme mutant background is necessary for the viability of lanosterol synthase mutants in aerobic conditions [36]. OSCs expression was induced in YPG medium (1\% yeast extract, $2 \%$ peptone, 2\% galactose) supplemented with hemin $(0.013 \mathrm{mg} / \mathrm{mL})$. A. thaliana OSC expression in SMY8[pSM60.21] was induced in YPG medium in presence of hemin $(0.013 \mathrm{mg} / \mathrm{mL})$ and ergosterol $(0.02 \mathrm{mg} / \mathrm{mL})$ Cells of SMY8[pSOB1.1] were grown aerobically at $30{ }^{\circ} \mathrm{C}$ to early stationary phase in synthetic complete medium without uracil SC-Ura $(0.17 \%$ yeast nitrogen base, $0.2 \%$ amino acids, $0.5 \%$ ammonium sulphate), with glucose $(2 \%)$ in presence of hemin $(0.013 \mathrm{mg} / \mathrm{mL})$ and ergosterol $(0.02 \mathrm{mg} / \mathrm{mL})$. Human OSC expression was induced in SC-Ura medium with galactose $(2 \%)$ in presence of hemin $(0.013 \mathrm{mg} / \mathrm{mL})$.

\subsection{Enzyme assays}


Cell-free homogenates were obtained as described [38]. Briefly, after lysis of the cell wall with lyticase, the spheroplasts were homogenized with a Potter device. Proteins in the homogenate were quantified with a protein assay kit (Sigma), based on the method of Lowry modified by Peterson [39] using bovine serum albumin as a standard.

OSC activity was assayed as described [38]. Briefly, the homogenates were incubated with labeled $\left[{ }^{14} \mathrm{C}\right]-(3 \mathrm{~S})-2,3$-oxidosqualene $(1000 \mathrm{cpm})$. The enzymatic reaction was terminated by the addition of $\mathrm{KOH}$ in methanol $(10 \% \mathrm{w} / \mathrm{v})$, the lipids were saponified at $80{ }^{\circ} \mathrm{C}$ for $30 \mathrm{~min}$ and nonsaponifiable lipids were extracted with petroleum ether. Extracts were spotted on TLC plates using n-hexane/ethyl acetate (85:15) as the developing solvent. The conversion of labelled substrate to labelled product was determined by using a System 200 Imaging Scanner (Hewlett-Packard, Palo Alto, CA, USA).

OSC inhibition was carried out, as described above, by incubating the homogenates with labeled $\left[{ }^{14} \mathrm{C}\right]-(3 \mathrm{~S})-2,3$-oxidosqualene $(1000 \mathrm{cpm})$ in the presence of inhibitors. $\mathrm{IC}_{50}$ values (inhibitor concentrations that reduced the enzymatic conversion by 50\%) were calculated by non-linear regression analysis of the residual activity versus the log of inhibitor concentration using statistical software from Genstat (NAG, Oxford, UK).

\subsection{MTT assay [32]}

HL 60 cells (German Collection of Microorganisms and Cell Cultures, DSMZ, Braunschweig, Germany) were maintained in RPMI 1640 medium (PAA Laboratories, Cölbe, Germany) containing $10 \%$ fetal bovine serum (FBS, PAA Laboratories, Cölbe, Germany) without antibiotics at $37{ }^{\circ} \mathrm{C}$ in a humidified atmosphere containing $5 \% \mathrm{CO}_{2}$. Solutions of the compounds in DMSO ( $1 \mu \mathrm{L}$, concentrations ranging from $10^{-9}$ to $\left.10^{-4} \mathrm{~mol} / \mathrm{L}\right)$ were incubated with $99 \mu \mathrm{L}$ of a suspension of HL 60 cells $\left(9 \times 10^{5}\right.$ cells $\left./ \mathrm{mL}\right)$ in RPMI 1640 medium with 10 $\%$ FBS in 96 well plates for $24 \mathrm{~h}$ at $37{ }^{\circ} \mathrm{C}$. Then, $10 \mu \mathrm{L}$ of MTT solution in PBS $(5 \mathrm{mg} / \mathrm{mL})$ were added and the plate was incubated for another $2 \mathrm{~h}$. The cells were quenched with $190 \mu \mathrm{L}$ DMSO and after $1 \mathrm{~h}$ of continuously shaking of the plates a photometric evaluation on an ELISA plate reader MRX II (Dynex Technologies, Denkendorf, Germany; Software: Revelation 4.06) using the wavelength of $550 \mathrm{~nm}$ followed. The $\mathrm{IC}_{50}$-values were calculated by using Prism 4 (GraphPad Software, La Jolla, USA).

\subsection{Assay for cholesterol biosynthesis inhibition}

The whole cell assay for cholesterol biosynthesis inhibition was carried out on HL 60 cells as described by us previously [24]. 


\section{Acknowledgments}

We thank the University of Turin, and the regional government (Regione Piemonte) for financial support of this research to G.B., further we thank S. Matsuda (Rice University) for providing recombinant yeast strains.

\section{References}

[1] P.D.G. Dean, Steroidologia 2 (1971) 143-157.

[2] J.-L. Giner, C. Djerassi, Phytochemistry 39 (1995) 333-335.

[3] E.J. Corey, H. Cheng, C.H. Baker, S.P.T. Matsuda, D. Li , X. Song, J. Am. Chem. Soc. 119 (1997) 1289-1296.

[4] K.U. Wendt, K. Poralla, G.E. Schulz, Science 277 (1997) 1811-1815.

[5] R. Thoma, T. Schulz-Gasch, B.D'Arcy, J. Benz, J. Aebi, H. Dehmlow, M. Hennig, M. Stihle, A. Ruf, Nature 432 (2004) 118-122.

[6] D.J. Reinert, G. Balliano, G.E. Schulz, Chem. Biol. 11 (2004) 121-126.

[7] O.H. Morand, J.D. Aebi, H. Dehmlow, Y.-H. Ji, N. Gains, H. Lengsfeld, J. Himber, J. Lipid Res. 38 (1997) 373-390.

[8] S. Jolidon, A.-M. Polak, P. Guerry, P.G. Hartman, Biochem. Soc. Trans. 18 (1990) 47-48. [9] I.C. Rose, B.A. Sharpe, R.C. Lee, J.H. Griffin, J.O. Capobianco, D. Zakula, R.C. Goldman, Bioorg. Med. Chem. 4 (1996) 97-103.

[10] F.S. Buckner, J.H. Griffin, A.J. Wilson, W.C. Van Voorhis, Antimicrob. Agents Chemother. 45 (2001) 1210-1215.

[11] J.C. Hinshaw, D.-Y. Suh, P. Garnier, F.S. Buckner, R.T. Eastman, S.P.T. Matsuda, B.M. Joubert, I. Coppens, K.A. Joiner, S. Merali, T.E. Nash, G.D. Prestwich, J. Med. Chem. 46 (2003) 4240-4243,

[12] G. Balliano, H. Dehmlow, S. Oliaro-Bosso, M. Scaldaferri, S. Taramino, F. Viola, G. Caron, J. Aebi, J. Ackermann, Bioorg. Med. Chem. Lett. 19 (2009) 718-723.

[13] D. Staedler, C. Chapuis-Bernascono, H. Dehmlow, H. Fisher, L. Jullierat-Jeanneret, J.D. Aebi, J. Med. Chem. 55 (2012) 4990-5002.

[14] L. Cattel, M. Ceruti, G. Balliano, F. Viola, G. Grosa, F. Rocco, P. Brusa, Lipids 30 (1995) 235-46. 
[15] A. Lenhart, D.J. Reinert, J.D. Aebi, H. Dehmlow, O.H. Morand, G.E. Schulz, J. Med. Chem. 46 (2003) 2083-2092.

[16] G.R. Brown, A.J. Foubister, M.C. Johnson, N.J. Newcombe, D. Waterson, S.L. Wells, Bioorg. Med. Chem. Lett. 11 (2001) 2213-2216.

[17] R.C. Goldman, D. Zakula , J.O. Capobianco, B.A. Sharp, J.H. Griffin, Antimicrob. Agents Chemother. 40 (1996) 1044-1047.

[18] S. Oliaro-Bosso, F. Viola, S. Matsuda, G. Cravotto, S. Tagliapietra, G. Balliano, Lipids 39 (2004)1007-1012.

[19] S. Oliaro-Bosso, F. Viola, S. Taramino, S. Tagliapietra, A. Barge, G. Cravotto, G. Balliano, ChemMedChem 2 (2007) 226-233.

[20] Y.F. Zheng, A.C. Oehlschlager, N.H. Georgopapadakou, P.G. Hartman, P. Scheliga, J. Am. Chem. Soc. 117 (1995) 670-680.

[21] M. Mark, P. Müller, R. Maier, B. Eisele, J. Lipid Res. 37 (1996) 148-158.

[22] D. Renard, J. Perruchon, M. Giera, J. Müller, F. Bracher, Bioorg. Med. Chem. 17 (2009) 8123-8137.

[23] M. Giera, F. Plössl, F. Bracher, Steroids 72 (2007) 633-642.

[24] M. Giera, D. Renard, F. Plössl, F. Bracher, Steroids 73 (2008) 299-308.

[25] A. Horling, C. Müller, R. Barthel, F. Bracher, P. Imming, J. Med. Chem. 76 (2012) 7614-7622.

[26] A. Windaus, W. Grundmann, L. Ann. 524 (1936) 295-299.

[27] P. Milla, F. Viola, S. Oliaro-Bosso, F. Rocco, L. Cattel, B.M. Joubert, R.J. LeClair, S.P.T. Matsuda, G. Balliano, Lipids, 37 (2002) 1171-1176.

[28] M.M. Meyer, M.J.R. Segura, W.K.Wilson, S.P.T. Matsuda, Angew. Chem. Int. Ed. 39 (2000) 4090-4092.

[29] H. H. Inhoffen, G. Quinkert, S. Schütz, D. Kampe, G.F. Domagk, Chem. Ber. 90 (1957) 664-673.

[30] R.D. Hoffsommer, D. Taub, N.L. Wendler, J. Org. Chem. 27 (1962) 4134-4137.

[31] G. Balliano, F. Viola, M. Ceruti, L. Cattel, Biochim. Biophys. Acta 959 (1988) 9-19.

[32] T. Mosmann, J. Immunol. Methods 65 (1983) 55-63.

[33] M. Ceruti, G. Balliano, F. Viola, L. Cattel, N. Gerst, F. Schuber, Eur. J. Med. Chem. 22 (1987) 199-208.

[34] R.B. Field, C.E. Holmund, N.F. Whittaker, Lipids 14 (1979) 741-747

[35] M. Ceruti, G. Balliano, F. Rocco, P. Milla, S. Arpicco, L. Cattel, F. Viola, Lipids 36 (2001) 629-636 
[36] E.J. Corey, S.P.T. Matsuda, C.H. Baker, A.Y. Ting, H. Cheng, Biochem. Biophys. Res. Commun. 219 (1996) 327-331.

[37] E.J. Corey, S.P.T. Matsuda, B. Bartel, Proc. Natl. Acad. Sci. USA 90 (1993) 1162811632

[38] S. Oliaro-Bosso, S. Taramino, F. Viola, S. Tagliapietra, G. Ermondi, G. Cravotto, G.

Balliano, J. Enzyme Inhib. Med. Chem. 24 (2008) 589-598.

[39] G.L. Peterson, Anal. Biochem. 83 (1977) 346-356. 